\title{
Spatial Analysis of a Tuberculosis Incidence in Magelang City in 2021
}

Amira Nada Fatikha*, Martini, Retno Hestiningsih, Nissa Kusariana

Department of Epidemiology and Tropical Diseases, Faculty of Public Health, Universitas Diponegoro, Indonesia

*corresponding author, e-mail: amiranadafatikha@gmail.com

\section{ARTICLE INFO}

Article history

Received 08/16/21

Revised 10/13/21

Accepted 11/05/21

Keywords

Tuberculosis,

Spatial Analysis,

Risk Factors

\section{ABSTRACT}

Background: Tuberculosis is a health problem of global concern, especially in Southeast Asia. Indonesia is the secondlargest contributor to tuberculosis after India. Some causes influence the increasing burden of tuberculosis in Indonesia, including environmental and socio-economic factors. Therefore, spatial analysis is needed to see the distribution of tuberculosis cases based on risk factors. This study focuses on conducting spatial analysis in Magelang City. Methods: This research is a quantitative descriptive observational study using an ecologic study approach. The sample size in this study was 38 tuberculosis patients with total sampling. Data collection was carried out using observation sheets. Data analyzed by software ArcGIS. Results: The spatial pattern of distribution occurred according to the low population density (97.4\%), the environmental temperature meet the requirements (84.2\%), the air humidity meet the requirements $(100 \%)$, the BCG immunization coverage was not being meet $(100 \%)$, the distance to health services is close $(100 \%)$, the household with low-level social welfare is at the most $(23.7 \%)$. Conclusion: An urban village with the highest tuberculosis cases is in the household with low-level social welfare is at the most. There is a need to improve social welfare and coverage of BCG immunization.

This is an open access article under the CC-BY-SA license.

\section{Introduction}

Tuberculosis is an infectious disease caused by the bacterium Mycobacterium tuberculosis. The source of transmission comes from tuberculosis patients with positive Acid-fast bacilli (Basil Tahan Asam/BTA +) through the microscopic sputum that they cough up. Tuberculosis is a global concern. In 2019, there were an estimated 10 million (range from 8.9 to 11.0 million) cases of tuberculosis. It was also estimated that 60 million lives were saved through the diagnosis and treatment of tuberculosis between 2000 and 2019. Geographically, the most tuberculosis patients in 2019 were in the Southeast Asian region (44\%). Indonesia is the second largest contributor to tuberculosis after India (8.5\%) [1-3].

In 2019, tuberculosis cases in Indonesia were 562,049 cases. There were 73,171 tuberculosis cases in Central Java in 2019, which increased compared to 2018 of 49,616 cases. Tuberculosis cases in Magelang City were recorded in 2018 of 979 cases, increased in 2019 by 1,103 cases, and increased again in 2020 by 646 cases. The Incident Rate (IR) of new tuberculosis patients in Magelang City in 2018 was 765/100,000 population, and in 2019 it was $1032 / 100,000$ population. In Magelang City in 2018, related to tuberculosis cases, there were as many as 38 deaths, in 2019 as many as 20 deaths, and in 2020 as many as 26 deaths [4-5].

There were causes that influence the increasing number of tuberculosis cases in Indonesia; those were including environmental and socio-economic factors. Unemployment rate, education level, per capita income level, sanitation conditions, climate, accessibility of health 
services, inadequate food and clothing, and low BCG immunization resulted in a high risk of people contracting tuberculosis [6-8].

The Geographic Information System presented spatial information that discussed the relationship between a place and its surrounding environment by overlaying two maps which then produced a new map resulting from the analysis. Through spatial analysis, the incidence of tuberculosis could be determined by observing the number of patients in an area at a certain time based on the related variables [9-10]. Thus, in this study, a Geographic Information System (GIS) application with the spatial analysis method would be used to describe the distribution of tuberculosis per kelurahan (village) as the unit of analysis in Magelang City.

\section{Method}

This research was a quantitative descriptive observational research using an ecologic study approach. The sampling technique used total sampling with a sample size of 38 tuberculosis patients who were recorded and monitored in Magelang City in January-March 2021. The dependent variable in this study was tuberculosis cases. Meanwhile, independent variables were BCG immunization coverage, population density, level of social welfare, environmental temperature, air humidity and distance of health services.

The data used were primary data and secondary data. Primary data was taken by means of field observations and measurements using a thermohygrometer. The secondary data were data on tuberculosis patients, BCG immunization coverage, as well as a list of hospitals and health centers in January-March 2021 in Magelang City from the Magelang City Health Office, data on the number of residents and area in Magelang City in the urban unit in March 2021 from Central Statistics Agency (BPS) of Magelang City, Integrated Data on Social Welfare (DTKS) in Magelang City in village units in March 2021 from the Social Affairs Office, data on the 2021 Magelang City administration map from the Regional Development Planning Agency (BAPPEDA).

Univariate analysis was performed using Microsoft Excel software to understand the characteristics of respondents and research variables. Map analysis was carried out using ArcGIS, an area mapping software, to determine the distribution of tuberculosis cases based on the variables analyzed spatially.

\section{Results and Discussion}

\subsection{Results}

Based on Table 1, it is known that the majority of tuberculosis sufferers in this study were aged 26-45 years as, many as 13 people (34.2\%); and male and female have the same number of 19 people (50\%).

Table 1. Respondents' Characteristics

\begin{tabular}{lcc}
\hline Respondents' Characteristics & $\mathbf{n}$ & $\%$ \\
\hline Age & 2 & \\
0-5 years & 2.3 \\
6-11 years & 1 & 2.6 \\
12-25 years & 4 & 1.5 \\
26- 45 years & 13 & 34.2 \\
46-65 years & 11 & 28.9 \\
66 years and above & 7 & 18.4 \\
Gender & & \\
$\quad$ Male & 19 & 50 \\
Female & 19 & 50 \\
\hline
\end{tabular}

It is known that the most cases of tuberculosis are in the Rejowinangun Utara Village $(23.7 \%)$ as many as 9 cases, of which 2 were cases of close contact (lived in the same house). And there were several villages that have no cases of tuberculosis (0\%) namely Magersari Village, Jurangombo Selatan Village, and Wates Village (Figure 1). 


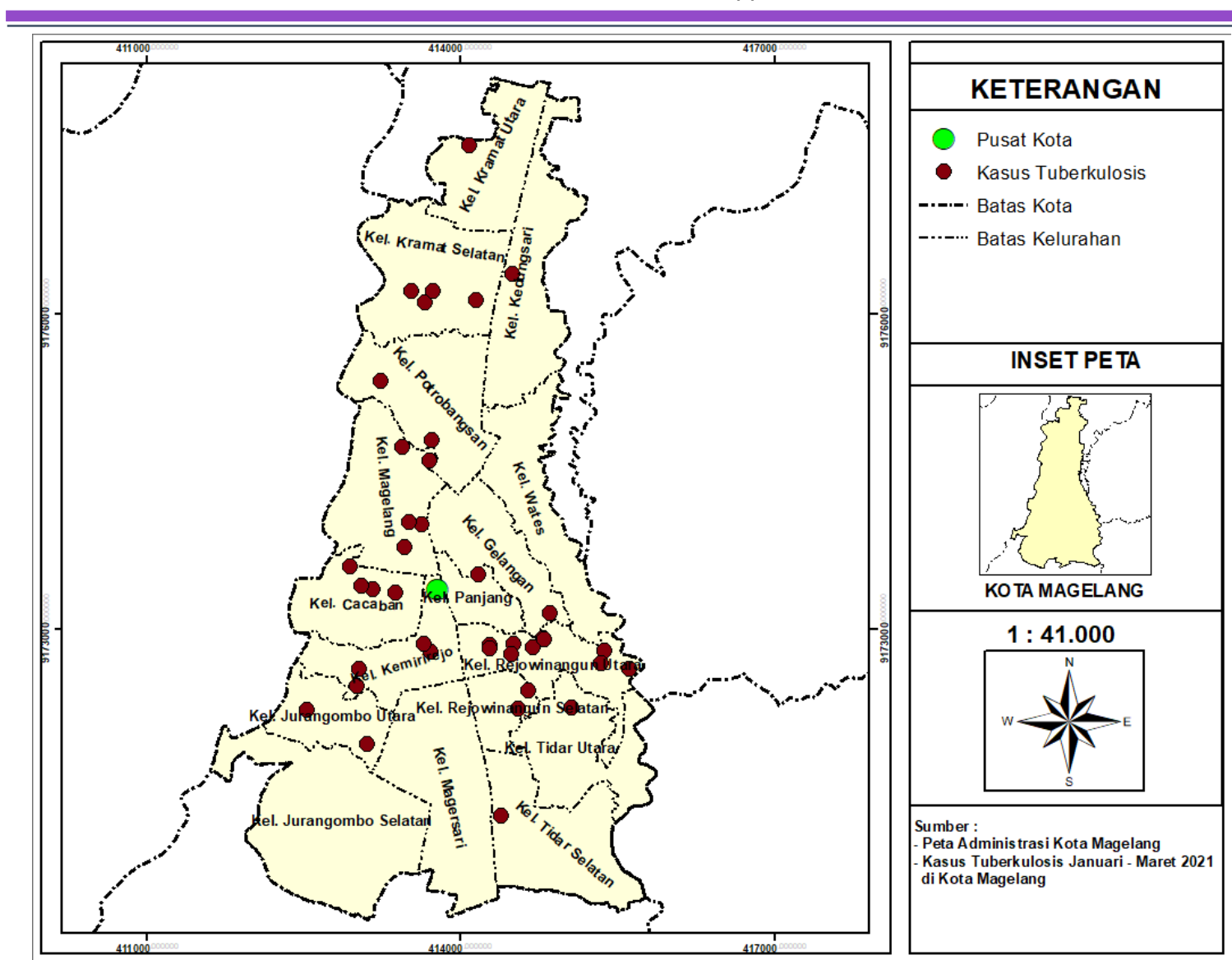

Figure 1. The Distribution of Tuberculosis Cases in Magelang City in January-March 2021

Figure 2 shows that most of the villages in Magelang City had a low population density $(88.2 \%)$ with a population of $<15,000$ people for every square kilometer of the area. Of the total tuberculosis cases in Magelang City, the distribution of cases tended to occur according to a low population density level with a case point of $97.4 \%$. Figure 3 shows that most of the urban areas in Magelang City had suboptimal temperatures, which was the ambient temperature less than $31^{\circ} \mathrm{C}$ and more than $37^{\circ} \mathrm{C}(76.5 \%)$. Of the total tuberculosis cases in Magelang City, the distribution of cases tended to occur according to the environmental temperature not in the range of $31^{\circ} \mathrm{C}-37^{\circ} \mathrm{C}$ with case points reaching $84.2 \%$.

Figure 4 shows that all villages in Magelang City were classified into areas that meet the requirements for air humidity $(100 \%)$, i.e., air humidity ranges from $45-65 \%$. The distribution of tuberculosis cases in Magelang City occured according to the air humidity that meets the requirements with the case point reaching $100 \%$. Figure 5 shows that the coverage of BCG immunization in Magelang City was included in the area where all the villages did not meet the BCG immunization coverage (100\%) which was $\leq 90 \%$ of the target.

Based on the conducted buffer analysis, the reach of the patient's house as far as $>5 \mathrm{~km}$ from health services was shown in green. Figure 6 shows that all villages in Magelang City were included in areas with close proximity to access health services (100\%). Figure 7 shows that in Magelang City, all the villages have households with low levels of social welfare. Of the total tuberculosis cases in Magelang City, $23.7 \%$ of the case points were spread in the Rejowinangun Utara Village which had households with the most of low level of social welfare $(13.7 \%)$. 


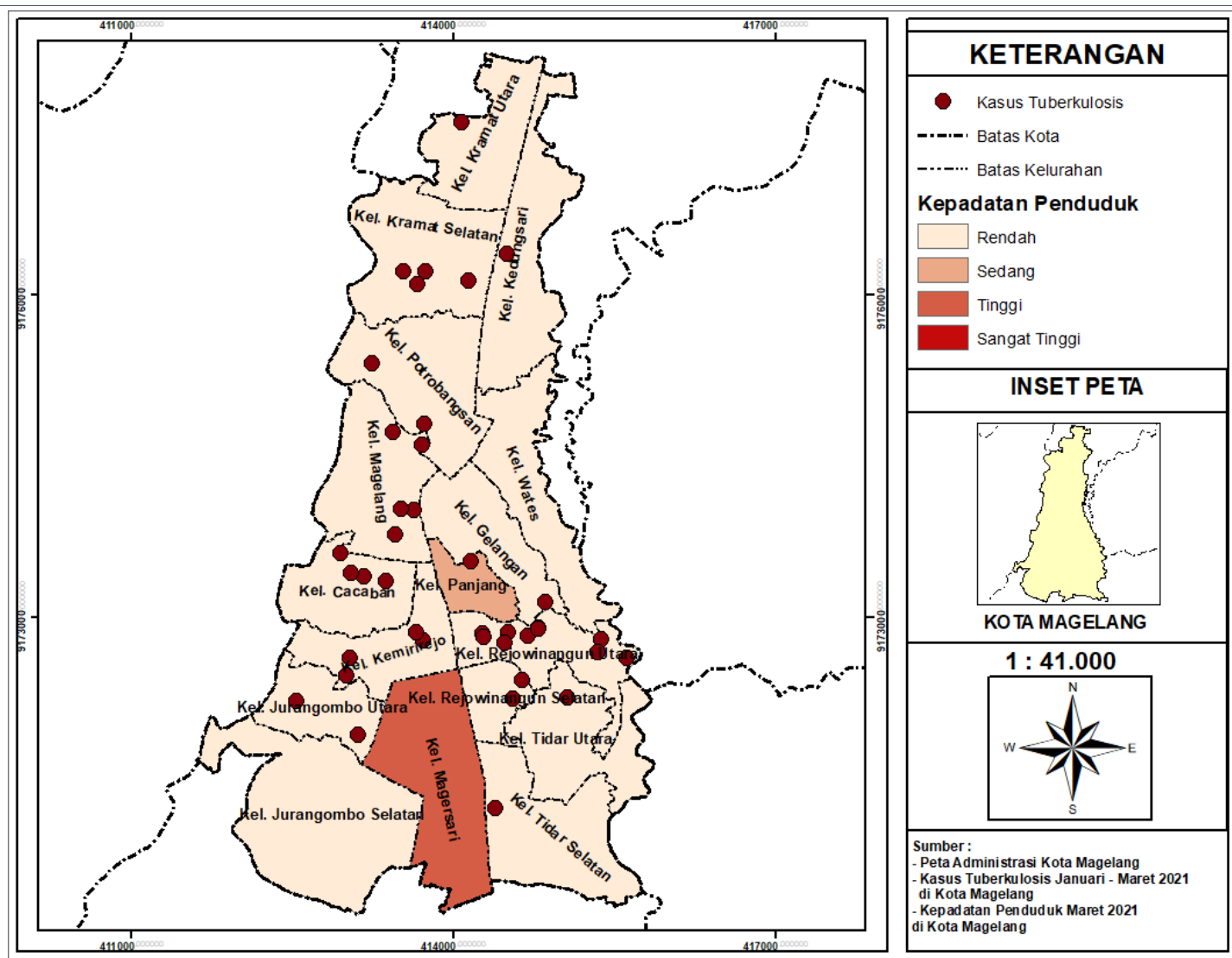

Figure 2. The Distribution of Tuberculosis Cases in Magelang City in January-March 2021 based on Population Density
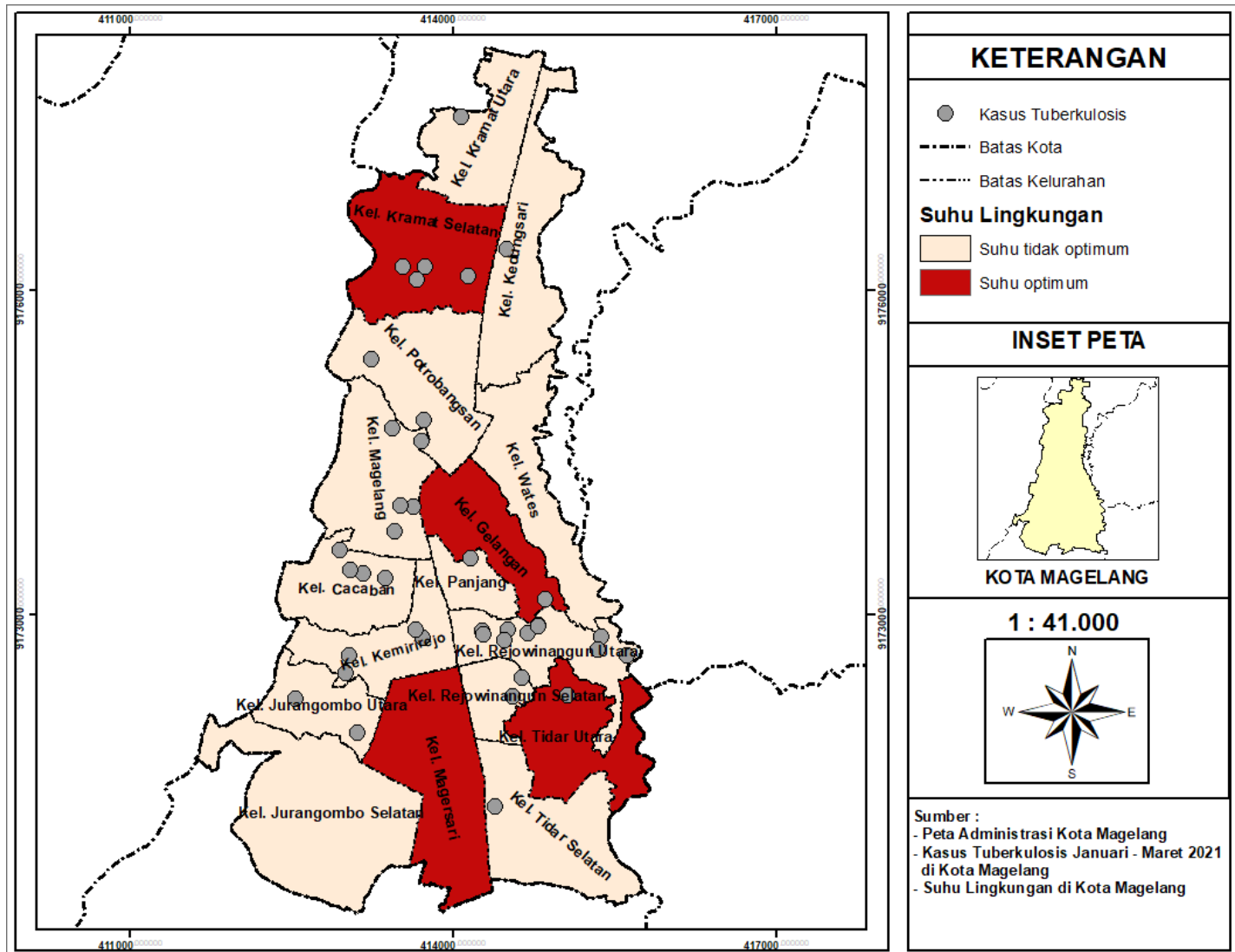

Figure 3. The Distribution of Tuberculosis Cases in Magelang City in January-March 2021 based on Environmental Temperature 


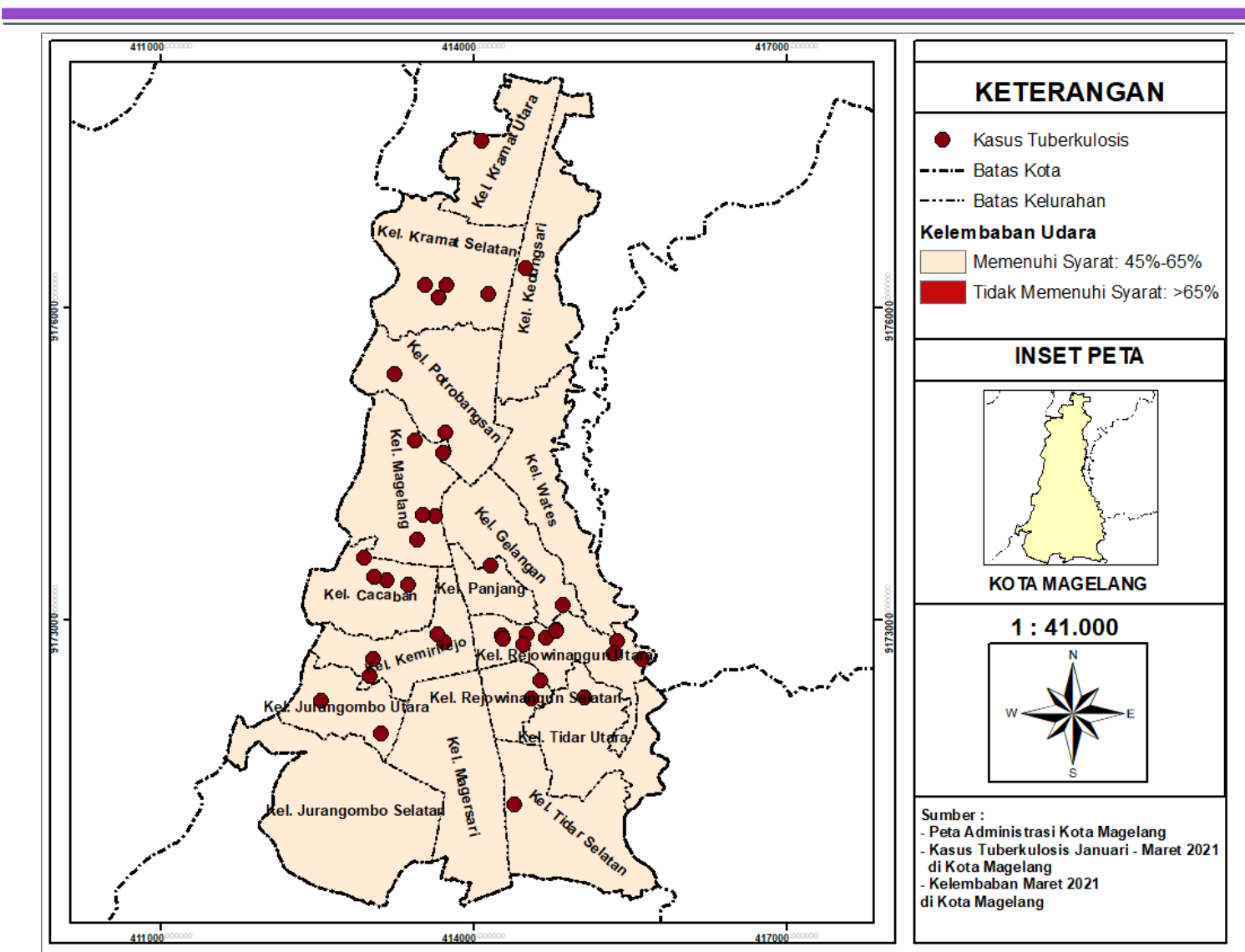

Figure 4. The Distribution of Tuberculosis Cases in Magelang City in January-March 2021 based on Air Humidity
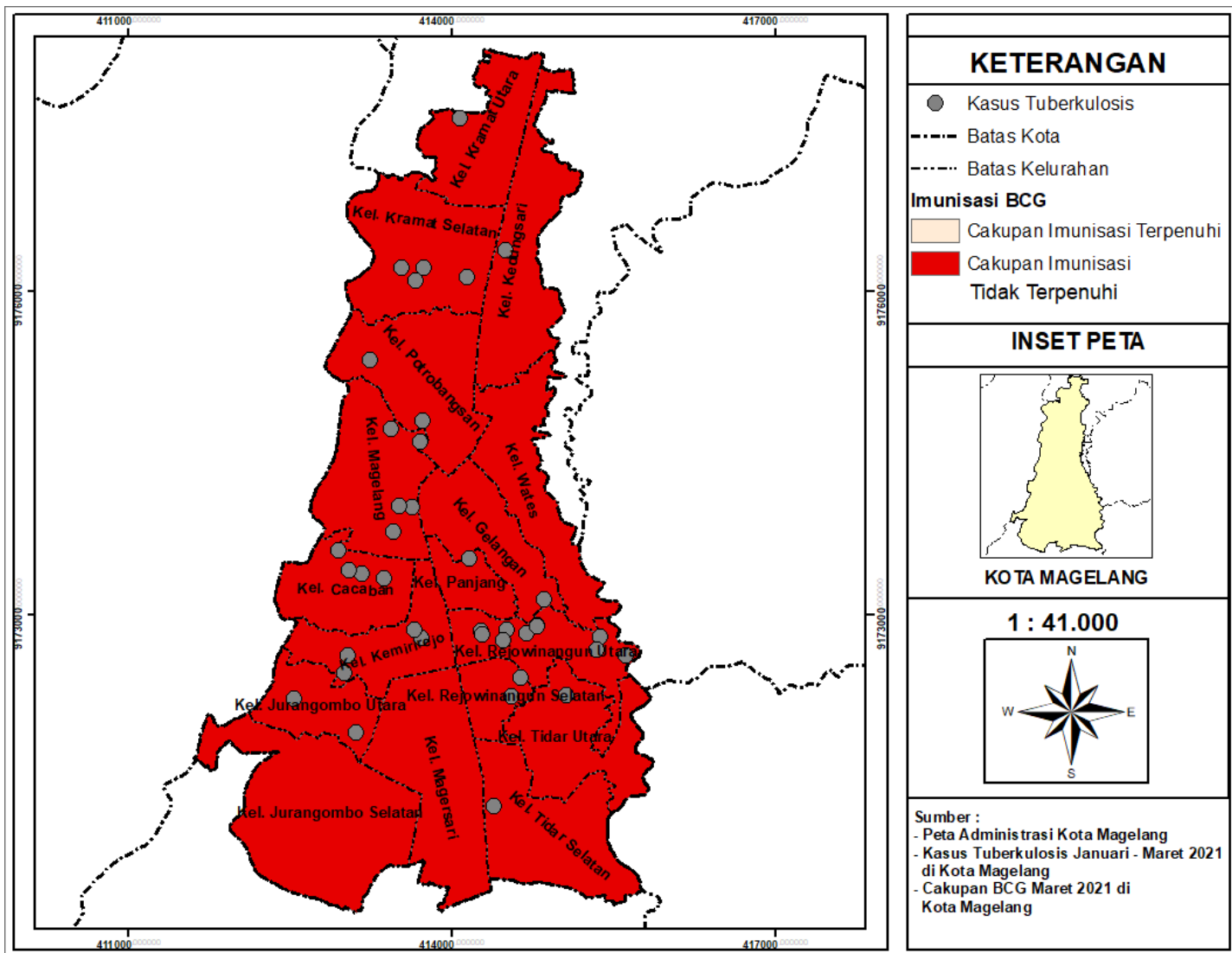

Figure 5. The Distribution of Tuberculosis Cases in Magelang City in January-March 2021 based on BCG Immunization Coverage 

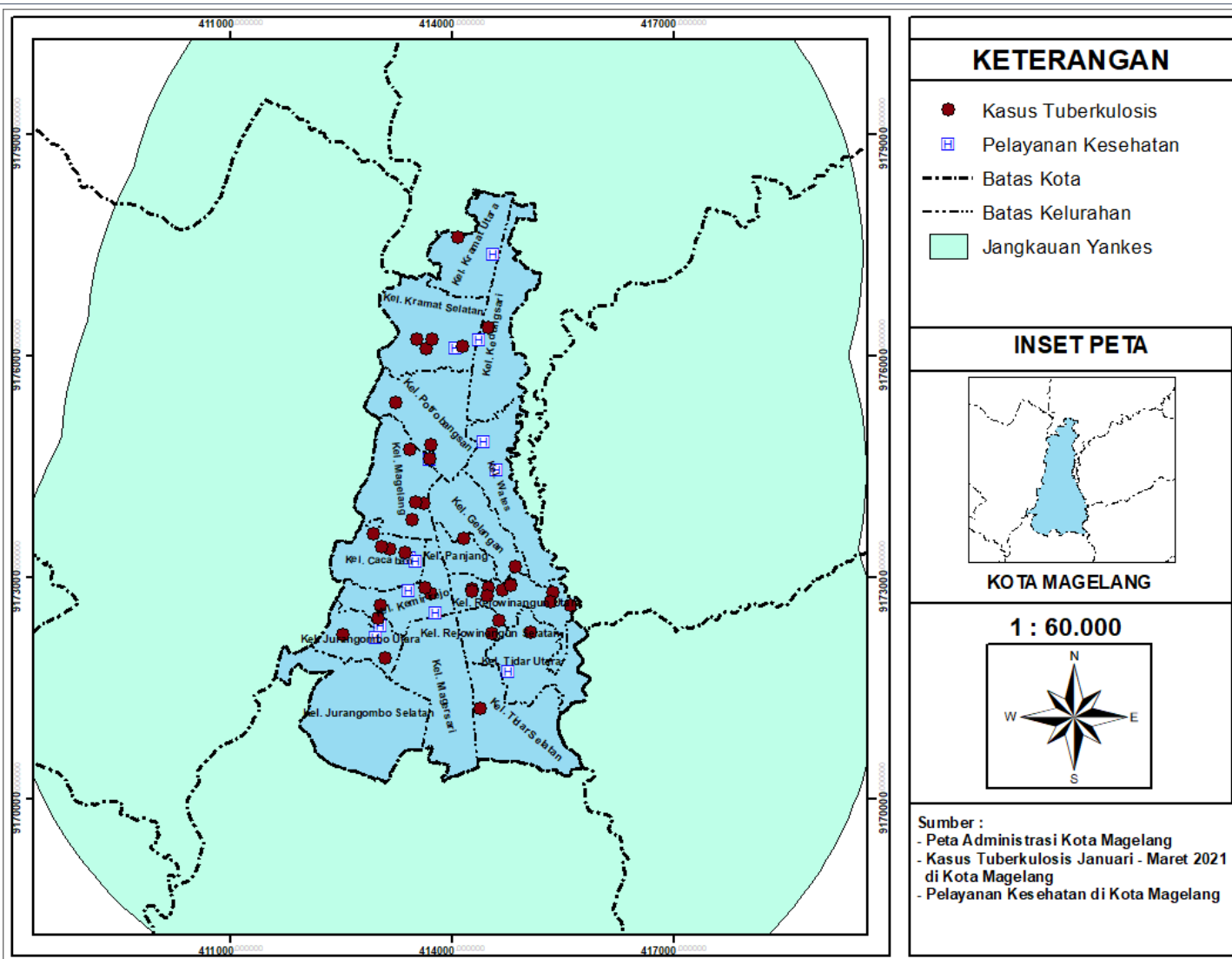

Figure 6. The Distribution of Tuberculosis Cases in Magelang City in January-March 2021 based on the Distance of Health Service
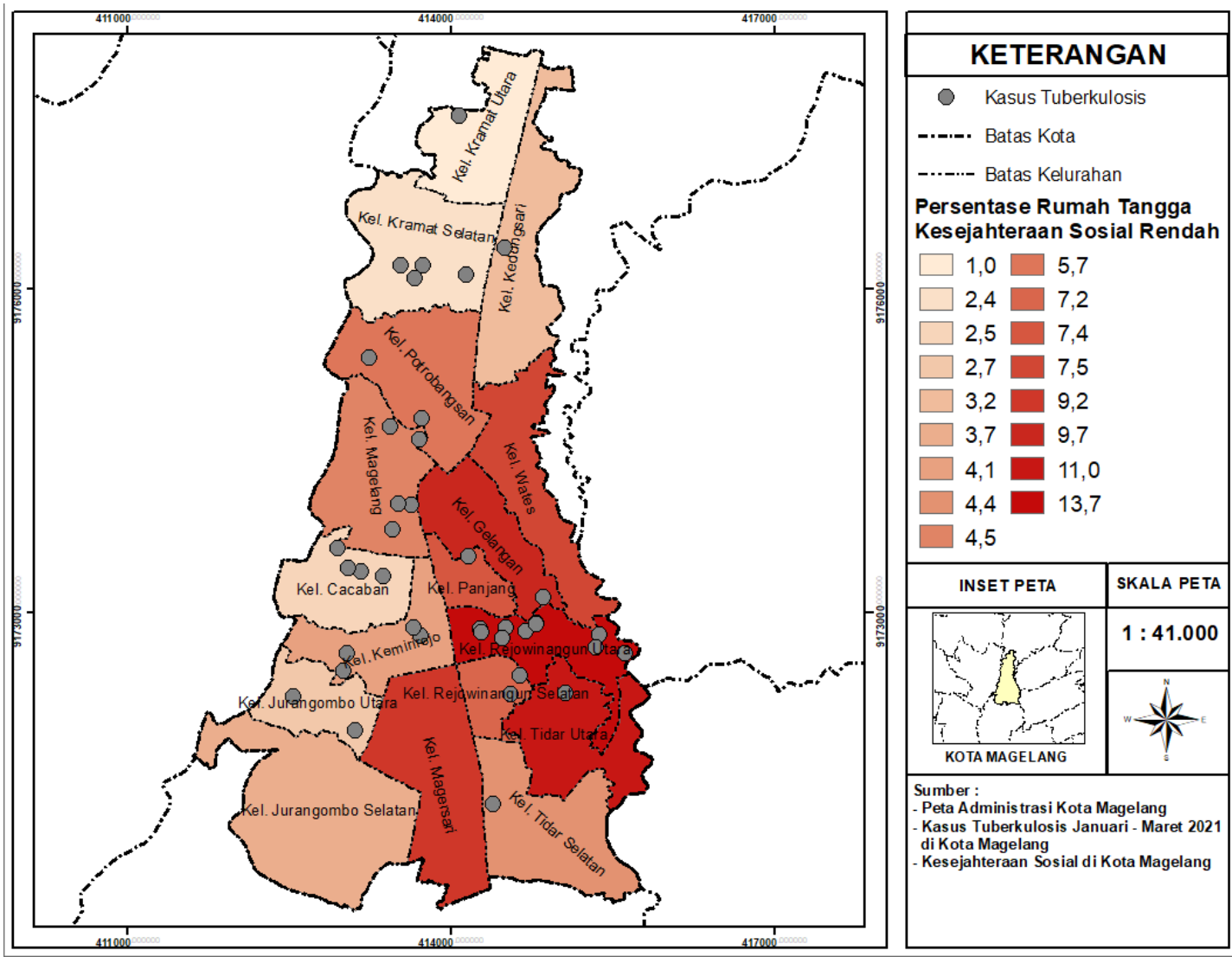

Figure 7. The Distribution of Tuberculosis Cases in Magelang City in January-March 2021 based on Social Welfare 


\subsection{Discussion}

In this study, cases of tuberculosis that were recorded and addressed in Magelang City in January-March 2021 were 38 cases with ages between 1-79 years. Tuberculosis cases mostly occurred in respondents in the adult category, between the ages of 26-45 years, as many as 13 people $(34 \%)$. This result was in line with another study which stated that the most common tuberculosis patients were adult patients (26-45 years) as many as $45.8 \%$ [11]. The adult age category was the productive age which at that age when respondents spent more time on social contact or socializing, and were at the stage of working or producing something for himself or others; so, there was a greater risk of spreading tuberculosis [12]. In addition, a lot of activity could affect the immune system [13]. There were $75 \%$ of tuberculosis patients which were in the most economically productive age (15-49 years). At that age, if a person suffered from tuberculosis, consequently it could result in low personal productivity or even burden the family. It was estimated that an adult tuberculosis patient would lose an average of 3-4 months of working time, resulting in a loss of $20-30 \%$ of his family's annual income [14]. The direct impact was in the form of medical expenses, while the indirect impact was in the form of loss of work productivity, which had an impact on social, family, and community problems [15-16].

Based on gender, tuberculosis sufferers in the months of January-March 2021 in Magelang City for male and female were the same (50\%). The prevalence of tuberculosis sufferers in Indonesia in male was 1.4 times more than female. The Tuberculosis Prevalence Survey showed the prevalence of men was three times higher than women. The same thing happened in other countries. This might be because men were more likely to be exposed to risk factors for tuberculosis, such as smoking and lacked of medication adherence [17-18]. Tuberculosis cases in January-March 2021 in Magelang City, which totaled 38 cases, showed that almost every village had tuberculosis cases. The distribution of cases in Magelang City tended to occur in the downtown area. Tuberculosis cases were the most in Rejowinangun Utara Village (23.7\%).

Population Density was calculated from the total population for every square kilometer of area in Magelang City in March 2021. The distribution of tuberculosis cases in January-March in Magelang City tended to occur according to a low population density $(97.4 \%)$ with a population of $<15,000$ people for every square kilometer of area. $2.6 \%$ of cases are spread in areas with moderate population density. Meanwhile, the village with a high population density has no cases of tuberculosis, namely in Magersari Village. The results of other studies also stated that the distribution of tuberculosis cases tended to be more common in low-density urban areas [19-20]. However, there were previous studies that have resulted in a spatial pattern for the distribution of a tuberculosis incidence was directly proportional to a high population density [21-22]. The denser population in certain areas, the spread of tuberculosis would be more likely to occur. And there was no difference in cases of tuberculosis in areas with high population density and low population density [23-24]. Population density could determine the speed of disease transmission, also determined the quality of health services and the number of patients in an emergency (the number of sufferers if there was a sudden change such as an extraordinary event). However, population density was not the only factor that caused tuberculosis bacterial infection. There were many other factors that could cause a person to be infected with tuberculosis bacteria, such as slum settlements, poverty, contact with tuvercolusis patients with AFB/BTA (+), and nutritional status [25-27].

Environmental temperature is the level of hot air in a place scaled in degrees Celsius $\left({ }^{\circ} \mathrm{C}\right)$ as measured by a thermohygrometer. Bacteria have a preferred temperature. At that temperature there is an optimal temperature that allows them to grow faster. Mycobacterium tuberculosis will grow optimally at a temperature of $31^{\circ} \mathrm{C}-37^{\circ} \mathrm{C}[11,28]$. The distribution of tuberculosis cases in Magelang City tended to occur according to the environmental temperature not in the range of $31^{\circ} \mathrm{C}-37^{\circ} \mathrm{C}$ with case points reaching $84.2 \%$. Meanwhile, the village with the optimal temperature, the environmental temperature which ranged from $31^{\circ} \mathrm{C}$ $37^{\circ} \mathrm{C}$, there were no cases of tuberculosis, which was in the Magersari Village. This result of this study was not in line with previous studies which stated that the environmental temperature of each sub-district had an average temperature which did not meet the requirements, with a temperature of $>30^{\circ} \mathrm{C}$. It showed the effect between the incidence of BTA (+) pulmonary tuberculosis with environmental temperature [12,29]. Environmental temperature was not the only risk factor for the incidence of pulmonary tuberculosis. Temperature could be influenced by climate including humidity, rainfall, and exposure to sunlight as well as geographical and topographical conditions. Tuberculosis disease could 
occur as a result of the accumulation of risk factors and disease agents that occurred simultaneously [14].

Air humidity was measured with a thermohygrometer. Air humidity in Magelang City showed that all villages were included in areas that meet the requirements for air humidity $(100 \%)$, air humidity ranging from $45 \%-65 \%$. The distribution of tuberculosis cases in Magelang City occurred according to the air humidity that meets the requirements with the case point reaching $100 \%$. The results of another study stated that the majority of tuberculosis patients were in areas with adequate humidity. However, there was a previous study which stated that as many as $85.8 \%$ of tuberculosis patients were in areas which did not meet the requirements for air humidity, namely $>70 \%$ [30]. High humidity (>65\%) could increase the life of tuberculosis bacteria. The water vapor content or air humidity of an area could be influenced by several factors such as air temperature, wind movement, air pressure, quality and quantity of sunlight, water availability, vegetation density, location altitude, and air density [16].

BCG Immunization Coverage was calculated from the percentage of the number of newborns who have received the BCG vaccine with the total number of newborns until March 2021. The distribution of tuberculosis cases in Magel City according to the unfulfilled BCG immunization coverage was $90 \%$ with case points reaching $100 \%$. Several villages with unfulfilled immunization coverage had no cases of tuberculosis, namely Wates Village, Magersari Village, and South Jurangombo Village. Of the total tuberculosis cases in Magelang City, $100 \%$ of the case points were spread in areas with unfulfilled BCG immunization coverage. This result of this study was not in line with previous studies which showed that the spatial distribution of tuberculosis occurred by region of high BCG immunization coverage with an increase in tuberculosis cases was in line with increased BCG immunization coverage and most of the point cases spread in areas with high immunization coverage. Giving BCG immunization would provide active immunity against tuberculosis, but the immunity that was formed did not guarantee a person to be infected with tuberculosis. If a person had received BCG immunization, the infection was not progressive and did not cause serious complications. Factors that affected the effectiveness of BCG immunization against tuberculosis included differences in the BCG vaccine given, high exposure to Mycobacterium tuberculosis bacteria in the environment, genetic factors, nutritional status and other factors that affected the quality of the vaccine such as the method of administration, dose, timing of BCG immunization, Vaccine storage, and UV exposure [7,17].

Health services in the City of Magelang included 8 public and private hospitals and 5 health centers. The distribution of tuberculosis cases in Magelang City occurred according to the distance of close health services, i.e., $5 \mathrm{Km}$ from health services with case points reaching $100 \%$. This was in line with previous studies which stated that the distribution of tuberculosis cases was close to health care, so that health services could be reached from the houses of people with tuberculosis [18]. However, there were other studies which stated that most of the places where people with tuberculosis live were far away from health services. The further distance health services were from the patient's house, the more it could affect the regularity treatment for tuberculosis sufferers $[19,20]$.

The level of social welfare was calculated using the decil calculation, where decil 1-4 $(40 \%)$ were households with low social welfare. In Magelang City, the most villages with the most of low level of household social welfare (13.7\%) were in Rejowinangun Utara Village. Of the total tuberculosis cases in Magelang City, Rejowinangun Utara Village had the highest number of tuberculosis cases $(23.7 \%)$. This was in accordance with the previous research which stated that the areas with the highest level of pre-prosperous household welfare (households that could not meet the indicators of basic family needs) were in the areas with the most tuberculosis cases [6]. The high prevalence of tuberculosis was related to the large number of slum settlements which showed that social welfare in the Jakarta area was still lacking. Sanitation and population density in slum areas were also at an alarming level. In fact, social welfare, sanitation, and density were factors that were closely related to tuberculosis. One study stated that low socioeconomic status had a two times higher risk of spreading tuberculosis [21,22]. There were studies that are not in line with the result of this study which stated that the pattern of the spread of tuberculosis tended not to follow the pattern of distribution of families with low social welfare (poor) [23]. 


\section{Conclusion}

Tuberculosis cases in January-March 2021 in Magelang City showed that almost every village had tuberculosis cases. The village in Magelang City with the highest tuberculosis cases was in the area with the most of low social welfare households. And all villages in Magelang City had unfulfilled BCG immunization coverage, so it was necessary to increase BCG immunization coverage.

\section{Declaration}

Conflict of Interest: No conflic of interest in this study Acknowledgments: None

\section{References}

1. World Health Organization. 2020. Global Tuberculosis Report 2020. Geneva: WHO Publication.

2. Kartasasmita CB. 2016. Epidemiologi Tuberkulosis. Sari Pediatri, 11(2):124-129. DOI: 10.14238/sp11.2.2009.124-9.

3. Dewi EF, Suhartono, Adi MS. 2016. Hubungan Faktor Lingkungan Rumah dengan Kejadian TB Paru di Kota Magelang. Jurnal Kesehatan Masyarakat, 4(149-159). https://ejournal3.undip.ac.id/index.php/jkm/article/view/11940.

4. Shimeles E, Enquselassie F, Aseffa A, Tilahun M, Mekonen A, Wondimagegn G, et al. (2019) Risk factors for tuberculosis: A case-control study in Addis Ababa, Ethiopia. PLoS ONE 14(4): e0214235. https://doi.org/10.1371/journal.pone.0214235

5. Amere, G. A., Nayak, P., Salindri, A. D., Narayan, K., \& Magee, M. J. (2018). Contribution of Smoking to Tuberculosis Incidence and Mortality in High-Tuberculosis-Burden Countries. American journal of epidemiology, 187(9), 1846-1855. https://doi.org/10.1093/aje/kwy081

6. Nafsi AY. 2020. Analisis Spasial Tuberkulosis Paru Ditinjau dari Faktor Demografi dan Tingkat Kesejahteraan Keluarga di Wilayah Pesisir (Studi Kasus di Wilayah Kerja Puskesmas Bandarharjo Kota Semarang). Jurnal Penelitian dan Pengembangan Kesehatan Masyarakat Indonesia, 1(1). https://journal.unnes.ac.id/sju/index.php/jppkmi/article/view/41419.

7. Sasmita S, Junaid J, Ainurafiq A. 2017. Pola Spasial Kejadian TB Paru BTA Positif Di Wilayah Kerja Puskesmas Puuwatu Tahun 2013-2015. Jurnal IImu Kesehatan Masyarakat, 2(6):1-10. DOI: 10.37887/jimkesmas.v2i6.3033.

8. Sihaloho ED, Alfarizy II, Sagala EB. 2019. Indikator Ekonomi dan Angka Tuberkulosis di Kabupaten Kota di Jawa Barat. Jurnal IImu Ekonomi dan Pembangunan, 19(2):136-46. https://jurnal.uns.ac.id/jiep/article/download/33698/25008.

9. Hastuti T, Ahmad, la Ode Ali Imran Ibrahim K. 2016. Analisis Spasial, Korelasi dan Tren Kasus TB Paru BTA Positif Menggunakan Web Sistem Informasi Geografis di Kota Kendari Tahun 2013-2015. Jurnal IImu Kesehatan Masyarakat, 1(3):152. DOI: 10.37887/jimkesmas.v1i3.1240.

10. Rahmawati H, Rahmaniati M. 2020. Analisis Spasial Kasus Baru Tuberkulosis BTA (+) terhadap Kepadatan Penduduk di Jawa Tengah Tahun 2016-2018. Jurnal IImu Kesehatan Masyarakat, 9(03):137-43. DOI: https://doi.org/10.33221/jikm.v9i03.498.

11. Kenedyanti E, Sulistyorini I. 2017. Analisis Mycobacterium Tuberkulosis dan Kondisi Fisik Rumah dengan Kejadian Tuberkulosis Paru. Jurnal Berkala Epidemiologi, 5(2):152-62. DOI: 10.20473/jbe.v5i2.2017.152-162

12. Aryanti Y, Astorina Yunita Dewanti N, 2019. Analisis Sebaran Kasus TB Paru BTA Positif di Kota Semarang Tahun 2018 berdasarkan Suhu Udara. Jurnal Kesehatan Masyarakat, 7(1). https://ejournal3.undip.ac.id/index.php/jkm/article/view/24448.

13. Kuncoro A, Asrifuddin A, Akili RH. 2016. Analisis Spasial Kejadian Tuberkulosis Paru di Manado Tahun 2014-2016. E-Journal Health, 1(1):1-12. https://jurnal.ugm.ac.id/bkm/article/download/42643/24537.

14. Lestari Muslimah DD. 2019. Keadaan lingkungan Fisik dan Dampaknya Pada Keberadaan Mycobacterium tuberculosis: Studi di Wilayah Kerja Puskesmas Perak Timur Surabaya. Jurnal Kesehatan lingkungan, 11(1):26. DOI: 10.20473/jkl.v11i1.2019.26-34.

15. Hartanto TD, Saraswati ID, Adi MS. 2019. Analisis Spasial Persebaran Kasus Tuberkulosis Paru di Kota Semarang Tahun 2018. Jurnal Kesehatan Masyarakat, 7(4):719-27. https://ejournal3.undip.ac.id/index.php/jkm/article/view/25123.

16. Fahdhienie F, Agustina A, Ramadhana PV. 2020. Analisis Faktor Risiko Terhadap Kejadian Penyakit Tuberkulosis Di Wilayah Kerja Puskesmas Pidie Kabupaten Pidie. SEI Jurnal Penelitian Kesehatan, 7(2):52-60. DOI: https://doi.org/10.22435/sel.v7i2.3735 
17. Suryaningtyas NH, Inzana N. 2020. Gambaran Kejadian TB Anak Berdasarkan Cakupan Imunisasi BCG dan lingkungan Rumah di Provinsi Jawa Tengah Tahun 2017 dan 2018. SEI Jurnal Penelitian Kesehatan, 7(1):19-32. DOI: https://doi.org/10.22435/sel.v7i1.3453

18. Risti Komala Dewi R, Selviana S. 2019. Analisis Spasial dan Gambaran Kejadian Tuberkulosis Paru pada Masyarakat di Wilayah Perbatasan. Jurnal Vokasi Kesehatan, 5(1):49-57. http://ejournal.poltekkes-pontianak.ac.id/index.php/JVK/article/view/210/pdf.

19. Selviana S, Hernawan AD, Khitama I. 2017. Analisis Spasial Sebaran Kasus dan Lingkungan Berpotensi Penularan Tuberkulosis Paru. J Vokasi Kesehat [Internet]. 2016;2(2):152-9. DOI: https://doi.org/10.30602/jvk.v2i2.71.

20. Simbolon D, Mutiara E, Lubis R. 2019. Analisis Spasial dan Faktor Risiko Tuberkulosis Paru di Kecamatan Sidikalang Kabupaten Dairi Tahun 2018. BKM Journal of Community Medicine and Public Health, 35 (2): 65-71. https://doi.org/10.22146/bkm.42643.

21. Rahayu IS, Alim HES, Purwanto SE, Amirullah G, Safitri DE, Dewanti IP. 2017. Analisis Situasi Tuberkulosis di Provinsi DKI Jakarta dengan Metode Root Cause Analysis (RCA). Seminar Hasil Penelitian Hibah, 1(1):277-90. https://proceedings.uhamka.ac.id/index.php/semnas/article/view/23.

22. Siroka A, Law I, Macinko J, Floyd K, Banda RP, Hoa NB, et al. 2017. The Effect of Household Poverty on Tuberculosis. International Journal Tuberculosis lung Disease, 20(12):1603-1618. https://www.ncbi.nlm.nih.gov/pmc/articles/PMC6037303/.

23. Yani Triningtyas A, Haifa Kuntara Putri T. 2019. Pola Penyebaran Tuberkulosis Paru di Kelurahan Utama Kecamatan Cimahi Selatan Tahun 2018. Medika Kartika Jurnal Kedokteran dan Kesehatan, 2(2):98-109. DOI: 10.35990/mk.v2n2.p98-109.

24. Yu, Y., Wu, B., Wu, C., Wang, Q., Hu, D., \& Chen, W. (2020). Spatial-temporal analysis of tuberculosis in Chongqing, China 2011-2018. BMC infectious diseases, 20(1), 531. https://doi.org/10.1186/s12879-020-05249-3

25. Wang, Y. S., Wang, J. M., \& Wang, W. B. (2020). Zhonghua liu xing bing xue za zhi= Zhonghua liuxingbingxue zazhi, 41(4), 526-531. https://doi.org/10.3760/cma.j.cn11233820190614-00441

26. Readhead, A., Chang, A. H., Ghosh, J. K., Sorvillo, F., Higashi, J., \& Detels, R. (2020). Spatial distribution of tuberculosis incidence in Los Angeles County. BMC public health, 20(1), 1434. https://doi.org/10.1186/s12889-020-09523-6

27. Corsi D. J. (2020). Spatial Epidemiology of Diabetes and Tuberculosis in India. JAMA network open, 3(5), e203892. https://doi.org/10.1001/jamanetworkopen.2020.3892

28. Alene, K. A., Viney, K., Moore, H. C., Wagaw, M., \& Clements, A. (2019). Spatial patterns of tuberculosis and HIV co-infection in Ethiopia. PloS one, 14(12), e0226127. https://doi.org/10.1371/journal.pone.0226127

29. Leal, B., Mesquita, C. R., Nogueira, L., Rodrigues, I., Oliveira, L. F., \& Caldas, R. (2019). Spatial analysis on tuberculosis and the network of primary health care. Revista brasileira de enfermagem, 72(5), 1197-1202. https://doi.org/10.1590/0034-7167-2017-0897

30. Sun, S. H., Gao, Z. D., Zhao, F., Zhang, W. Y., Zhao, X., Li, Y. Y., Li, Y. M., Hong, F., He, X. X., \& Zhan, S. Y. (2018). Zhonghua liu xing bing xue za zhi = Zhonghua liuxingbingxue zazhi, 39(6), 816-820. https://doi.org/10.3760/cma.j.issn.0254-6450.2018.06.023 